\title{
Correction: microRNA 31 functions as an endometrial cancer oncogene by suppressing Hippo tumor suppressor pathway
}

Takashi Mitamura ${ }^{1,2^{*}}$, Hidemichi Watari ${ }^{1}$, Lei Wang ${ }^{2}$, Hiromi Kanno ${ }^{2}$, Masaya Miyazaki ${ }^{2}$, Makiko Kitagawa ${ }^{1}$, Mohamed Kamel Hassan ${ }^{1,4}$, Peixin Dong ${ }^{5}$, Taichi Kimura², Mishie Tanino², Hiroshi Nishihara ${ }^{3}$, Shinya Tanaka ${ }^{2,3}$ and Noriaki Sakuragi ${ }^{1}$

\section{Correction}

After publication of this work [1], we noted that we inadvertently failed to include the complete list of all coauthors. The full list of authors has now been added and the Authors' Contributions and Competing Interests sections modified accordingly.

\section{Competing interests}

The authors declare that they have no competing interests.

\section{Authors' contributions}

TM, HW, HN, ST and NS designed the experiment, interpreted the data and prepared the manuscript. TM, LW, HK, MM, MK, MKH, PD, TK, MT conducted the experiment, collected the data and helped to prepare the manuscript. All authors read and approved the final manuscript.

\section{Author details}

${ }^{1}$ Department of Obstetrics and Gynecology, Hokkaido University Graduate School of Medicine, Sapporo, Japan. '²epartment of Cancer Pathology, Hokkaido University Graduate School of Medicine, Sapporo, Japan. ${ }^{3}$ Department of Translational Pathology, Hokkaido University Graduate School of Medicine, Sapporo, Japan. ${ }^{4}$ Biotechnology Program, Zoology Department, Faculty of Science, PS U, Port Said University, Port Fouad, Port Said, Egypt. ${ }^{5}$ Department of Women's Health Educational System, Hokkaido University School of Medicine, Hokkaido University, Sapporo, Japan.

Received: 16 May 2014 Accepted: 16 May 2014

Published: 4 June 2014

\section{Reference}

1. Takashi M, Hidemichi W, Lei W, Hiromi K, Makiko K, Mohamed Kamel H, Taichi K, Mishie T, Hiroshi N, Shinya T, Noriaki S: microRNA 31 functions as an endometrial cancer oncogene by suppressing Hippo tumor suppressor pathway. Mol Cancer 2014, 13:97.

\footnotetext{
* Correspondence: takami@huhp.hokudai.ac.jp

'Department of Obstetrics and Gynecology, Hokkaido University Graduate School of Medicine, Sapporo, Japan

${ }^{2}$ Department of Cancer Pathology, Hokkaido University Graduate School of Medicine, Sapporo, Japan
}

doi:10.1186/1476-4598-13-140

Cite this article as: Mitamura et al: Correction: microRNA 31 functions as an endometrial cancer oncogene by suppressing Hippo tumor suppressor pathway. Molecular Cancer 2014 13:140.

\section{Submit your next manuscript to BioMed Central and take full advantage of:}

- Convenient online submission

- Thorough peer review

- No space constraints or color figure charges

- Immediate publication on acceptance

- Inclusion in PubMed, CAS, Scopus and Google Scholar

- Research which is freely available for redistribution
C B̈̈omed Central (c) 2014 Mitamura et al.; licensee BioMed Central Ltd. This is an Open Access article distributed under the terms of the Creative Commons Attribution License (http://creativecommons.org/licenses/by/4.0), which permits unrestricted use, distribution, and reproduction in any medium, provided the original work is properly credited. The Creative Commons Public Domain Dedication waiver (http://creativecommons.org/publicdomain/zero/1.0/) applies to the data made available in this article, unless otherwise stated. 